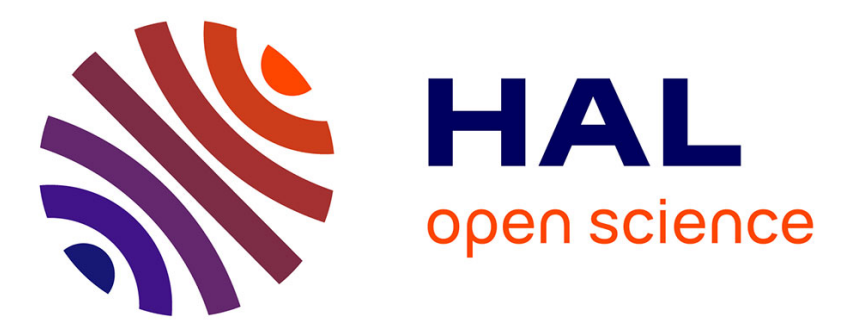

\title{
Selective Synthesis of THF-Derived Amines from Biomass-Derived Carbonyl Compounds
}

Shi Jiang, Changru Ma, Eric Müller, Marc Pera-Titus, François Jérôme, Karine de Oliveira Vigier

\section{- To cite this version:}

Shi Jiang, Changru Ma, Eric Müller, Marc Pera-Titus, François Jérôme, et al.. Selective Synthesis of THF-Derived Amines from Biomass-Derived Carbonyl Compounds. ACS Catalysis, 2019, 9 (10), pp.8893-8902. 10.1021/acscatal.9b03413 . hal-02331617

\section{HAL Id: hal-02331617 https://hal.science/hal-02331617}

Submitted on 19 Nov 2020

HAL is a multi-disciplinary open access archive for the deposit and dissemination of scientific research documents, whether they are published or not. The documents may come from teaching and research institutions in France or abroad, or from public or private research centers.
L'archive ouverte pluridisciplinaire HAL, est destinée au dépôt et à la diffusion de documents scientifiques de niveau recherche, publiés ou non, émanant des établissements d'enseignement et de recherche français ou étrangers, des laboratoires publics ou privés. 


\section{Selective synthesis of THF-derived amines from biomass-derived carbonyl compounds}

Shi Jiang, ${ }^{\dagger}$ Changru Ma, Eric Muller,${ }^{\S}$ Marc Pera-Titus, ${ }^{*}{ }^{*}$ François Jerôme ${ }^{\dagger}$ and Karine De Oliveira Vigier $*$

†Institut de Chimie des Milieux et Matériaux de Poitiers, CNRS_Université de Poitiers, 1 rue Marcel Doré, ENSIP, TSA 41195, 86073 Poitiers Cedex 9, France

Eco-Efficient Products and Processes Laboratory (E2P2L), UMI 3464 CNRS-Solvay, 3966 Jin Du Road, Xin Zhuang Ind. Zone, 201108 Shanghai, China

${ }^{\S}$ SOLVAY-Advanced Organic Chemistry \& Molecule Design Laboratory, Recherche \& Innovation Centre de Lyon, 85 Avenue des Frères Perret, 69192 Saint Fons, France 
ABSTRACT: Selective transformation of biomass or biomass-based feedstocks into value-added amines is highly desirable and constitutes one of the most important challenges in Catalysis. As of today, only few amination studies have been reported on bio-based substrates, targeting mainly the reductive amination of small platform molecules issued directly from biomass. Here we present a simple and highly efficient system using $\mathrm{NH}_{3}$ or amines as a nitrogen source and molecular hydrogen as reducing agent for the transformation of furan-derived ketones into THF-derived amines over $\mathrm{Pd} / \mathrm{Al}_{2} \mathrm{O}_{3}$ (up to $98 \%$ yield). Detailed analysis of the reaction system provided insight into the reaction mechanism. To further realize the production of THF-derived amines, a one-pot two-step strategy combining C-C and C-N condensation reactions was attempted. A high yield (85\%) towards 5-methyl-1-(tetrahydrofuran-2-yl)hexan-3-amine could be successfully achieved starting directly from furfural.

KEYWORDS: Biomass, Furfural, Aldol Condensation, Amination, Palladium 


\section{Introduction}

Amines represent a valuable class of compounds of wide interest in the chemical industry due to their nucleophilic properties, conferring them high reactivity. ${ }^{1-7}$ Among the different types of amines, primary amines constitute valuable fine and bulk chemicals, which serve as versatile feedstocks and key intermediates for the synthesis of advanced chemicals, life science molecules and polymers. ${ }^{8-11}$ Industrially relevant aliphatic and aromatic amines, as well as aminoalcohols, are currently manufactured from fossil resources. ${ }^{12}$ In contrast, transformation of biomass into valuable nitrogen-containing chemicals is still very limited owing to the lack of efficient amination methods for biomass-derived molecules. ${ }^{7,813,14}$ So far, the conversion of carbohydrates into valuable nitrogen compounds is a good opportunity and starts to be an important goal of research programs. ${ }^{15-19}$

The promotion of catalytic system for the selective and sustainable synthesis of amines from available and inexpensive starting materials using green reagents and mild reaction condition is highly demanded and challenging. ${ }^{19-22}$ As a rule, four mechanisms can be exploited for amine alkylation: (1) nucleophilic substitution of alkyl halides with amines; $;{ }^{12}$ (2) $\mathrm{N}$-alkylation of amines with alcohols under catalytic conditions, ${ }^{23,24}$ (3) reductive amination of carbonyl compounds with amines. $^{25}$ (4) hydroamination of olefins with amino source. ${ }^{26}$ The first method is not recommended from a green synthesis point of view, since a massive amount of useless inorganic salts is generated. Alkylation of amines with alcohols normally requires harsh conditions, especially high temperature or well-designed catalyst, as well as in some cases the use of additives. Hydroamination of olefins is acknowledged as a typical way for synthesis of aliphatic amines, combining alkenes and simple $\mathrm{N}-\mathrm{H}$ functional groups in a direct and atom-economical fashion. At the same time it is one of 10 challenges for catalysis and limited examples are reported, which 
promotes the potential to create a significant synthetic benefit. Direct reductive amination, involving the reaction of carbonyl compounds, represents one of the most versatile, and waste-free process to access a variety of amines..$^{6,10,20}$ However, overalkylation, reduction to the corresponding alcohols and poor catalyst stability are common drawbacks in catalytic processes for the direct synthesis of amines, especially in the presence of $\mathrm{NH}_{3} \cdot{ }^{27-35}$ Hence, from an atomeconomy and green standpoint, there is an urgent need to develop a selective and efficient system for producing bio-based primary amines, which is the prime task of this investigation.

Recently, we reported an efficient method for the synthesis of furfural from highly concentrated xylose in biphasic media, where furfural was extracted by methyl isobutyl ketone (MIBK). ${ }^{36}$ As a top chemical produced from biomass, furfural is furanic derivative that is available in large scale (>200 kT/year), making it an attractive raw material for the production of valueadded chemicals. ${ }^{37,38}$ For instance, furfural can be selectively converted into furfurylamine by reductive amination with $\mathrm{NH}_{3}$ in presence of $\mathrm{H}_{2},{ }^{39,40}$ which is used in the synthesis of pesticides, herbicides and pharmaceuticals (for diuretic furosemide synthesis). Besides, furan-based compounds are highly versatile and key derivatives used in the manufacture of a wide range of chemicals, and can serve as precursors for the synthesis of jet fuels substitutes or additives such as alkanes. $^{41-52}$

Herein, we present a simple and efficient catalytic system combining C-C and C-N condensation reactions for producing 5-methyl-1-(tetrahydrofuran-2-yl)hexan-3-amine, and extensively a library of THF-derived biobased amines with variable molecular complexity and diversity, starting directly from furfural (Scheme 1). In particular, $\mathrm{Pd} / \mathrm{Al}_{2} \mathrm{O}_{3}$ was found as an active catalyst for the highly selective formation of THF-derived primary amines using $\mathrm{NH}_{3}$ and $\mathrm{H}_{2}$ in an efficient one-step process starting from bio-derived ketone (methylisobutylketone, MIBK which 
is obtained from aceton a bulk chemical). This approach was successfully extended to the selective synthesis of a new family of THF-derived amines. The presence of the THF moiety is of prime importance for solvent properties and the manufacture of polymers. ${ }^{53-55}$

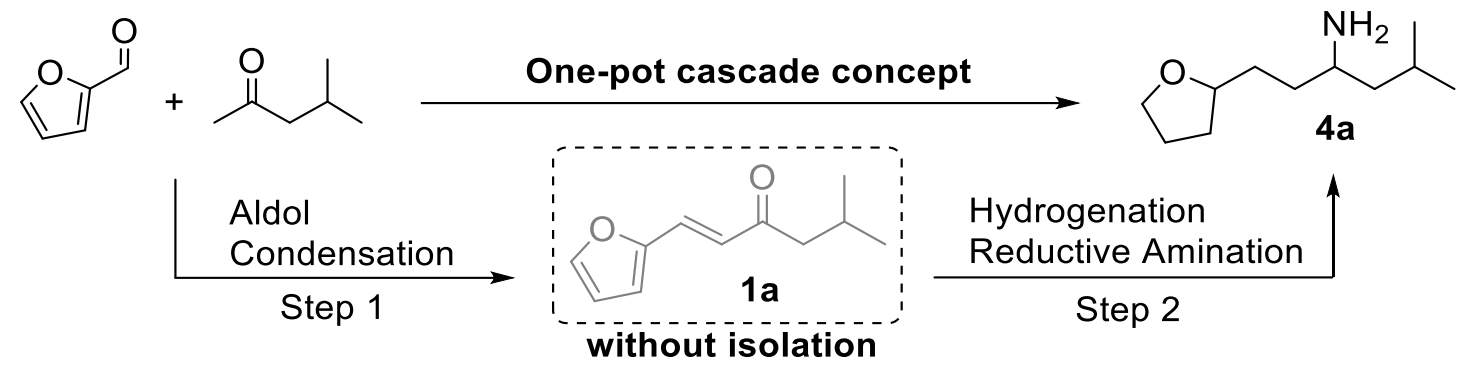

Scheme 1. Synthesis of THF-derived amines starting directly from furfural.

\section{Results and Discussion}

Catalyst Characterization. X-ray diffraction of all noble metal catalysts were performed and are shown in Figure 1.

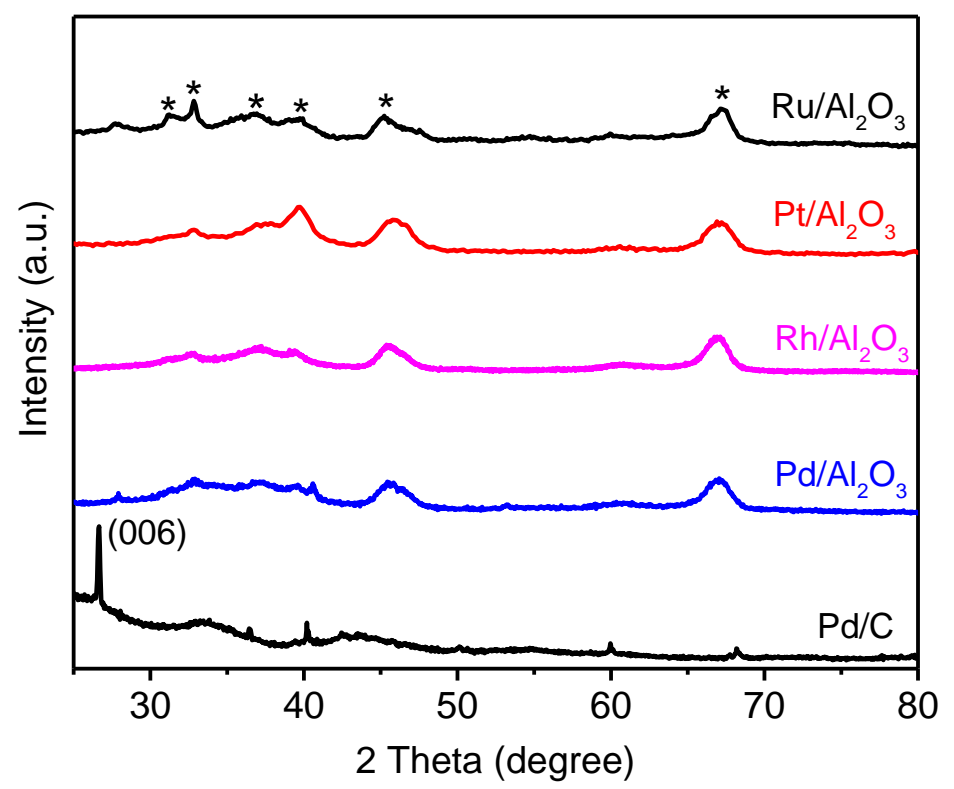

Figure 1. XRD patterns of all noble metal catalysts (peak indication: ${ }^{*}=\gamma-\mathrm{Al}_{2} \mathrm{O}_{3}$ ) 
The XRD patterns only contain features of the supports $\left(\mathrm{Al}_{2} \mathrm{O}_{3} / \mathrm{C}\right)$, implying the absence of large metal particles. The textural properties of the catalysts are listed in Table 1.

Table 1. Physical-chemical properties of all noble metal catalysts.

\begin{tabular}{cccc}
\hline Catalyst & $\mathrm{S}_{\text {BET }}\left(\mathrm{m}^{2} / \mathrm{g}\right)$ & Pore size $(\mathrm{nm})$ & Pore volume $\left(\mathrm{cm}^{3} / \mathrm{g}\right)$ \\
\hline $\mathrm{Ru} / \mathrm{Al}_{2} \mathrm{O}_{3}$ & 138 & 19.1 & 0.74 \\
$\mathrm{Pt} / \mathrm{Al}_{2} \mathrm{O}_{3}$ & 166 & 15.6 & 0.81 \\
$\mathrm{Rh} / \mathrm{Al}_{2} \mathrm{O}_{3}$ & 152 & 10.3 & 0.44 \\
$\mathrm{Pd} / \mathrm{Al}_{2} \mathrm{O}_{3}$ & 158 & 14.4 & 0.57 \\
$\mathrm{Pd} / \mathrm{C}$ & 1016 & 4.8 & 0.53 \\
\hline
\end{tabular}

The highest surface area is obtained for the carbon support $\left(1016 \mathrm{~m}^{2} / \mathrm{g}\right)$ and the other four aluminasupported catalysts show quite similar surface area (between 138 and $166 \mathrm{~m}^{2} / \mathrm{g}$ ). One can mention that the pore size is on the opposite, the lowest for Pd supported on carbon $(4.6 \mathrm{~nm})$ and for the other catalysts it in in the range of 10.3 to $19.1 \mathrm{~nm}$. The pore volume of all the catalysts are comprise between 0.44 to $0.81 \mathrm{~cm}^{3} / \mathrm{g}$.

XPS analysis was performed in order to identify the probable species of noble metals on the catalysts surfaces. The identification of the probable metal species is based on XPS patterns obtained from the National Institute of Standards and Technology (NIST). To correct binding energies (BEs), the $\mathrm{Al} 2 \mathrm{p}$ peak with $\mathrm{BE} 74.4 \mathrm{eV}$ for Al-containing samples and the adventitious carbon C 1s peak with BE $284.8 \mathrm{eV}$ are used as reference. Figure S1 presents the XPS spectra of selected $\mathrm{Ru}, \mathrm{Pt}, \mathrm{Rh}$ and $\mathrm{Pd}$ catalysts and binding energies of $\mathrm{Ru} 3 \mathrm{~d}_{5 / 2}, \mathrm{Pt} 4 \mathrm{~d}_{5 / 2}, \mathrm{Rh} 3 \mathrm{~d}_{5 / 2}$ and $\mathrm{Pd}$ $3 \mathrm{~d}_{5 / 2}$ for the analyzed solids. It is clearly noted that all noble metal species contained oxidized species due to passivation under air due to experimental work up. However, reduced species are the main species for all the catalysts. Hence, Pt, Rh, Pd catalysts could be sufficiently reduced into metallic species at room temperature whereas $\mathrm{H}_{2}$-temperature-programmed reduction (Figure $\mathrm{S} 2$ ) reveals that $\mathrm{Ru}$ on $\mathrm{Al}_{2} \mathrm{O}_{3}$ can be reduced into metallic $\mathrm{Ru}$ at the reaction temperature $90{ }^{\circ} \mathrm{C}$. These 
results indicate that all the noble metal catalysts contain mostly metallic species under the reaction conditions.

Catalytic Testing. On the guidance of a previous study, ${ }^{56}$ a bio-based carbonyl-conjugated vinylfuran (1a) was selected as model platform, which can be selectively synthesized by the aldol condensation reaction of furfural with methyl isobutyl ketone (MIBK). The reductive amination of 1a with $\mathrm{NH}_{3}$ to the primary amine using $\mathrm{H}_{2}$ was chosen as benchmark reaction. Due to the polyfunctionnality of $\mathbf{1 a}(\mathrm{C}=\mathrm{C}, \mathrm{C}=\mathrm{O}$ bonds and furanic cycle $)$, various products can be in principle generated, including furanic ketone (2a), THF-derived ketone (3a), THF-derived amine (4a), or furanic amine (5a). Targeting the selective synthesis of amine products and more specifically $\mathbf{4 a}$, a series of commercially available noble metal catalysts based on $\mathrm{Ru}, \mathrm{Pt}, \mathrm{Rh}$ and $\mathrm{Pd}(5 \mathrm{wt} \%$ metal) supported over alumina $\left(\mathrm{Al}_{2} \mathrm{O}_{3}\right)$ or active carbon $(\mathrm{C})$ were screened, and the results are shown in Table 2.

In a first set of experiments, $0.2 \mathrm{~g}$ of $\mathbf{1 a}(10 \mathrm{wt} \% \mathrm{in} \mathrm{EtOH})$ was reacted in the presence of 10 mg of the alumina-supported $\mathrm{Ru}, \mathrm{Pt}, \mathrm{Rh}$ and $\mathrm{Pd}$ catalysts at $120^{\circ} \mathrm{C}$ for $12 \mathrm{~h}$ with 5 bar $\mathrm{NH}_{3}$ and 20 bar $\mathrm{H}_{2}$. Except for $\mathrm{Pd} / \mathrm{Al}_{2} \mathrm{O}_{3}$, a complex mixture of $\mathbf{2 a - 5 a}$ products was obtained. In particular, $\mathrm{Ru}$ and Pt favored the formation of the furanic amine $5 \mathbf{a}$ with $\sim 50 \%$ yield, but the latter exhibited a lower carbon balance which is probably due to condensation reaction. Rh afforded the formation of all the products with a yield of $8 \%, 10 \%, 46 \%$ and $33 \%$ of products $2 \mathbf{a}, 3 \mathbf{3 a}, \mathbf{4 a}$ and $\mathbf{5 a}$, respectively. In the presence of $\mathrm{Pd} / \mathrm{Al}_{2} \mathrm{O}_{3}$, the yield of product $4 \mathbf{a}$ was around $90 \%$ with a carbon mass balance over $95 \%$. We further investigated the effect of the support on the catalytic properties. $\mathrm{Pd} / \mathrm{C}$ afforded $83 \%$ and $5 \%$ yield of products $\mathbf{4 a}$ and $\mathbf{3 a}$, respectively, with a carbon mass balance of $88 \%$. When the $\mathrm{Pd} / \mathrm{Al}_{2} \mathrm{O}_{3}$ catalyst loading was decreased to $5 \mathrm{mg}$, a drop of the 
4a yield (from $92 \%$ to $71 \%$ ) was observed along with an increase of the $3 \mathbf{a}$ yield from $7 \%$ to $23 \%$. In light of these results, we further optimized the process conditions for the $\mathrm{Pd} / \mathrm{Al}_{2} \mathrm{O}_{3}$ catalyst.

Table 2. Reductive amination of 1a over supported metal catalysts ${ }^{\mathrm{a}}$

\begin{tabular}{llllll} 
& & & & \\
\hline
\end{tabular}

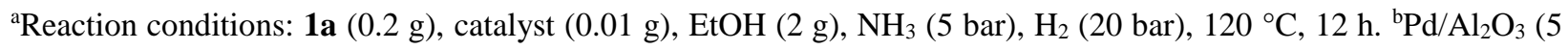
$\mathrm{mg}$ ). The 1a conversion was over $99 \%$ for all catalysts

Effect of the Reaction Temperature. To attain high selectivity to product $\mathbf{4 a}$ at mild conditions and also to understand the reaction mechanism, the effect of the reaction temperature on the catalytic properties was first investigated (Figure 2a). No effect was observed on the 1a conversion, but the product distribution differed substantially. Indeed, a decrease of the temperature from $120^{\circ} \mathrm{C}$ to $80{ }^{\circ} \mathrm{C}$ led to a drastic decrease of the yield of THF-derived amine $4 \mathbf{a}$ from $90 \%$ to $33 \%$ to the benefit of the furanic ketone (2a) and furanic amine (5a). A further decrease of the temperature down to $50{ }^{\circ} \mathrm{C}$ resulted in few amine products at the expense of a mixture the hydrogenated products $\mathbf{2 a}$ and 3a with a yield of $44 \%$ and $39 \%$, respectively, at full 1a conversion. These results suggest that a temperature below $80{ }^{\circ} \mathrm{C}$ is insufficient for generating the amine products with good selectivity within $12 \mathrm{~h}$, which might be attributed to a faster 
hydrogenation of the ketone compared to the intermediate imine. In light of these results, a reaction temperature of $120{ }^{\circ} \mathrm{C}$ was selected to ensure the formation of THF-derived amine $\mathbf{4 a}$.
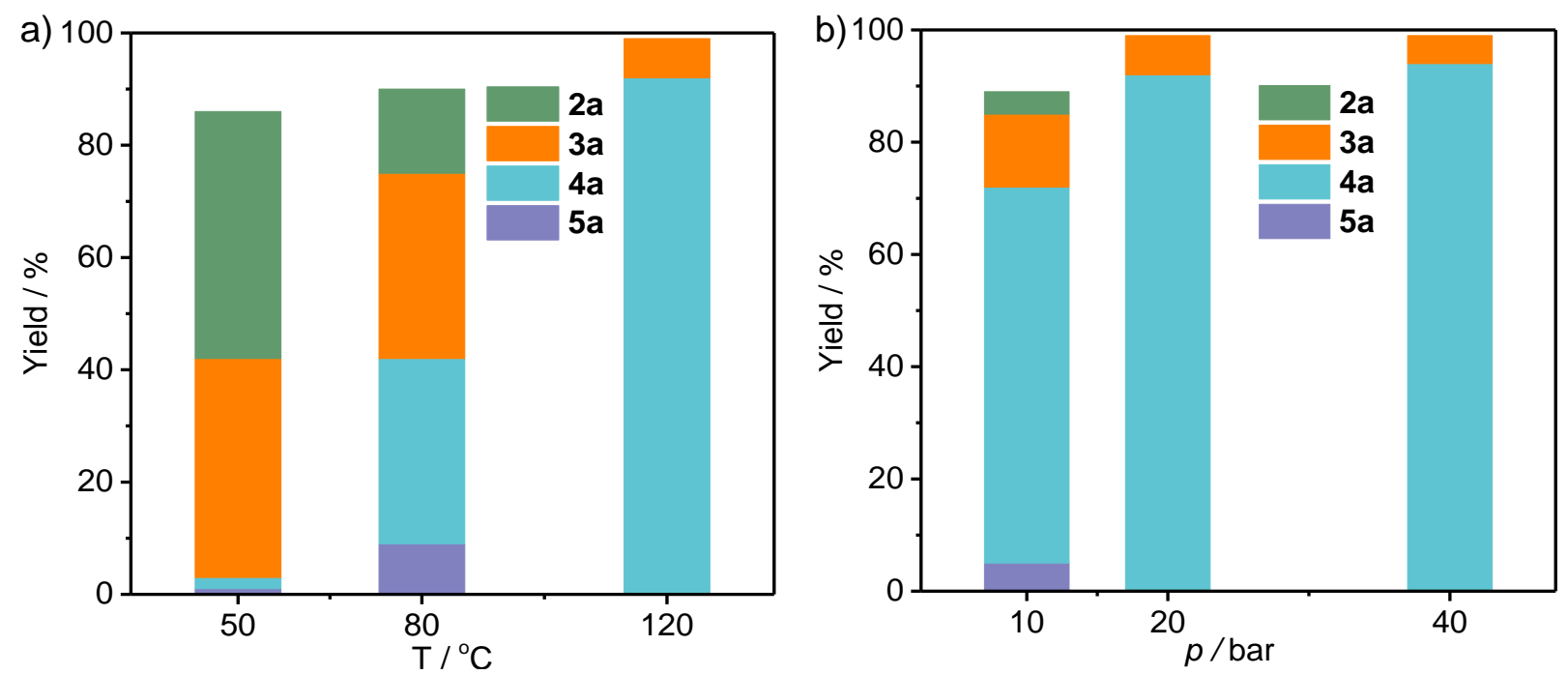

Figure 2. a) Effect of temperature; b) Effect of $\mathrm{H}_{2}$ pressure on the catalytic performance of $\mathrm{Pd} / \mathrm{Al}_{2} \mathrm{O}_{3}$ in the reductive amination of 1a. Reaction Conditions: a) $\mathrm{Pd} / \mathrm{Al}_{2} \mathrm{O}_{3}(10 \mathrm{mg}, 0.42 \mathrm{~mol} \%$, 1a (0.2 g), EtOH (2 g), $\mathrm{NH}_{3}$ (5 bar), $\mathrm{H}_{2}$ (20 bar), 12 h; b) $\mathrm{Pd} / \mathrm{Al}_{2} \mathrm{O}_{3}(10 \mathrm{mg}), 1 \mathrm{a}(0.2 \mathrm{~g}), \mathrm{EtOH}(2$ g), $\mathrm{NH}_{3}\left(5\right.$ bar), $120{ }^{\circ} \mathrm{C}, 12 \mathrm{~h}$. The $1 \mathrm{a}$ conversion was over $99 \%$ in all the tests.

Effect of the Hydrogen Pressure. $\mathrm{H}_{2}$ as the reducing agent plays an important role in the reaction (1 mol of reagent 1a could consume $4 \mathrm{~mol}$ of $\mathrm{H}_{2}$, Scheme 2). Thus, we investigated the effect of the $\mathrm{H}_{2}$ pressure keeping the other parameters constant (Figure 2b). When the $\mathrm{H}_{2}$ pressure was decreased from 20 bar to 10 bar, the yield of the THF-derived amine 4a decreased from $92 \%$ to $67 \%$ to the benefit of $\mathbf{2 a}, \mathbf{3 a}$ and $\mathbf{5 a}$ with a yield of 5\%, $13 \%$ and 4\%, respectively. In contrast, an increase of the $\mathrm{H}_{2}$ pressure from 20 bar to 40 bar did not result in an appreciable change of the catalytic performance ( $94 \%$ yield of $\mathbf{4 a}$ and $4 \%$ yield of $\mathbf{3 a}$ ). These results point out two possible pathways for generating the THF-derived primary amine (Scheme 2): (i) hydrogenation of the furanic amine, or (ii) reductive amination of the THF-derived ketone. One can mention that the 
formation of the Schiff base is likely to occur in the presence of amine and ketone in organic solvent. However, due to the electronic hindrance of the ketone or amine groups, we did not detect its existence in our work.

(i)

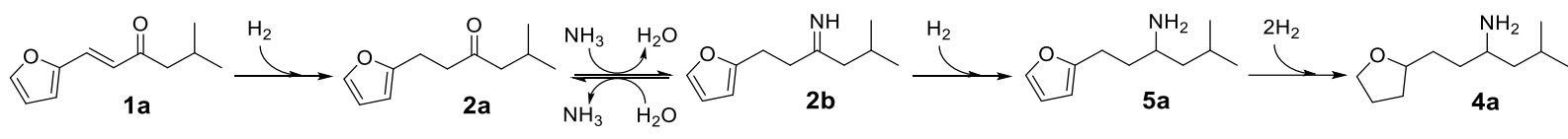

(ii)

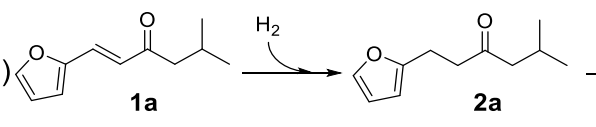

Scheme 2. Possible reaction pathways for generating THF-derived amines: (i) reductive amination of THF-derived ketone; and (ii) hydrogenation of the furanic amine.

To sort out the contribution of both pathways, DFT calculations at the CCSD(T)/cc-pVTZ level were conducted to unveil the thermodynamic stability of the different products (Figure 3, see calculation details in the SI). In the presence of $\mathrm{H}_{2}$, carbonyl-conjugated vinylfuran (1a) was first converted into the furanic ketone (2a) with a free energy of reaction $\left[\Delta \mathrm{G}^{\mathrm{o}}(1 \mathrm{a} \rightarrow 2 \mathrm{a})\right]$ of $-13.8 \mathrm{kcal}$ $\mathrm{mol}^{-1}\left(120^{\circ} \mathrm{C}\right.$, in ethanol). In the presence of $\mathrm{NH}_{3}$, a narrowly positive free energy of reaction compared to $\mathbf{2 a}\left[\Delta \mathrm{G}^{\mathrm{o}}(2 \mathrm{a} \rightarrow 2 \mathrm{~b})=+8.3 \mathrm{kcal} \mathrm{mol}^{-1}\right]$ pushed the formation of the furan imine $\mathbf{2 b}$, followed by the hydrogenation to the furanic amine $5 \mathbf{a}\left[\Delta \mathrm{G}^{\mathrm{o}}(2 \mathrm{~b} \rightarrow 5 \mathrm{a})=-8.6 \mathrm{kcal} \mathrm{mol}^{-1}\right]$. Finally, by deep hydrogenation, the THF-derived amine can be generated with a further stabilization $\left[\Delta \mathrm{G}^{\mathrm{o}}\right.$ $\left.(2 \mathrm{a} \rightarrow 4 \mathrm{a})=-14.9 \mathrm{kcal} \mathrm{mol}^{-1}\right]$ compared to $\mathbf{2 a}$. In the meantime, in the presence of $\mathrm{H}_{2}$, a thermodynamically more favorable reaction can occur driven by the hydrogenation of the furan

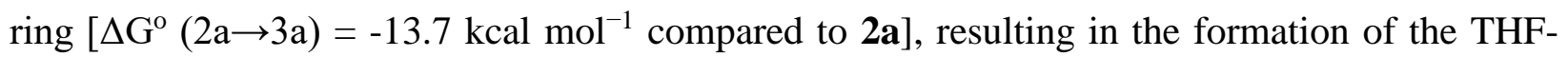
derived ketone (3a). Then the THF-derived amine can be accessed by the reductive amination of 3a. In light of these results, from a thermodynamic perspective, pathway (ii) appears to be more 
feasible for generating THF-derived amines. Here we only calculated the free energies of the reactions, not the barriers. Thus the reaction kinetics was not considered in the calculations.

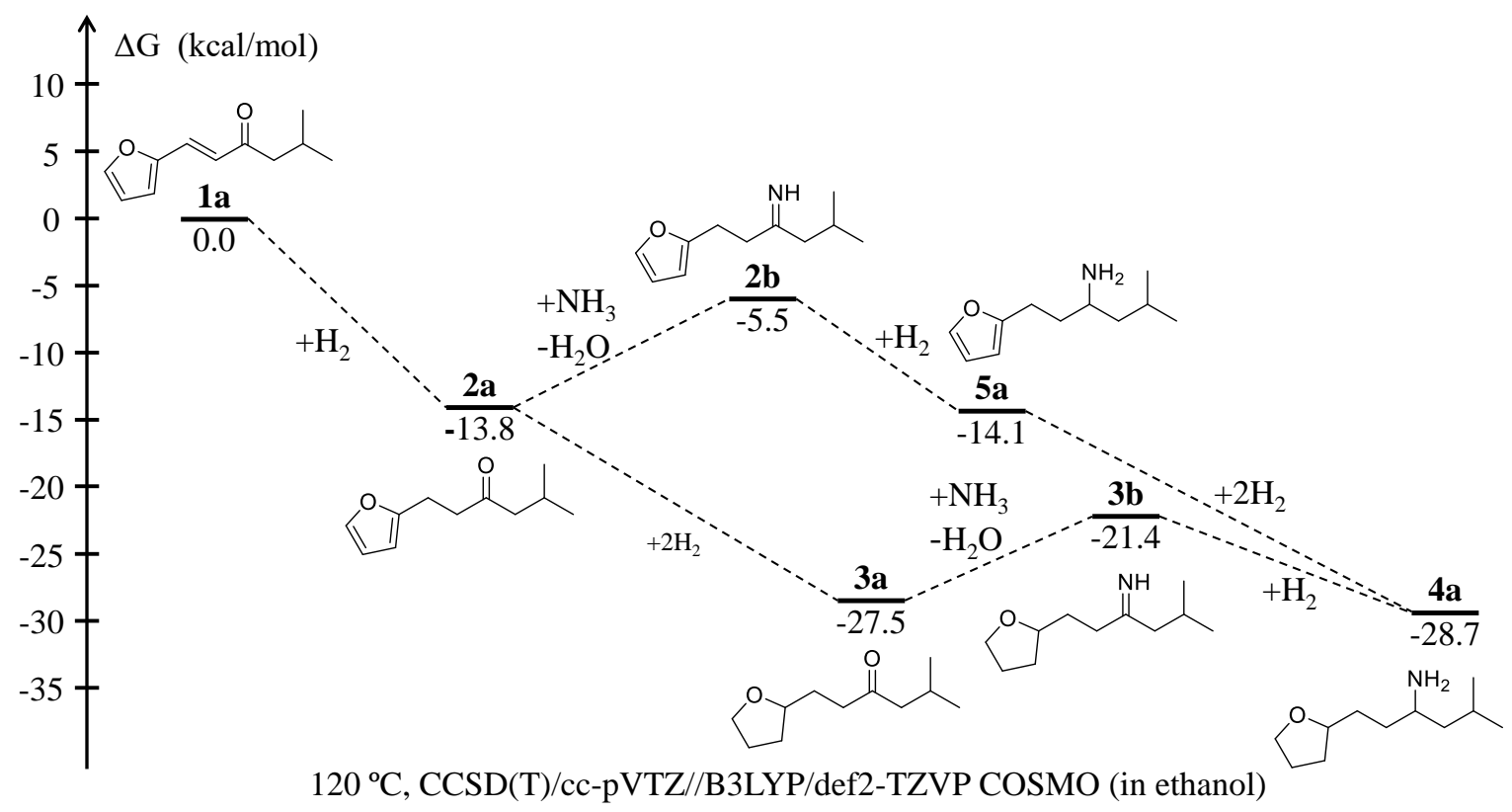

Figure 3. Free energy diagrams for the reductive amination of $\mathbf{1 a}$ and related reactions; Values in parentheses are the computed free energies referred to $\mathbf{1 a .}$

Reaction Kinetics. We further measured the kinetics of the formation of the different products over $\mathrm{Pd} / \mathrm{Al}_{2} \mathrm{O}_{3}$ by varying the reaction time from 1 min to $18 \mathrm{~h}$ (Figure 4 ). The results show a complete transformation of the product mixture into $\mathbf{4 a}$ from the very beginning of the reaction. Indeed, after $1 \mathrm{~min}, 50 \%$ of reactant $\mathbf{1 a}$ was converted into $\mathbf{2 a}$ and $\mathbf{3 a}$ with $28 \%$ and $8 \%$ yield, respectively, with little formation of the amine and imine products. This observation suggests a faster hydrogenation rate of the vinyl group after 1 min of reaction $\left(\mathbf{2 a}, 0.315 \mathrm{mmol} \mathrm{min}^{-1}\right)$ compared to the furan ring (3a, $\left.0.090 \mathrm{mmol} \mathrm{min}^{-1}\right)$. After $2 \mathrm{~min}, \mathbf{1 a}$ was fully converted into a mixture of products $2 \mathbf{a}$ and 3a, whereas when the reaction was prolonged to $20 \mathrm{~min}$, the target 
product $4 \mathbf{a}$ started to be generated, reaching a maximum yield of $98 \%$ after $18 \mathrm{~h}$. These results point out that, on a kinetic perspective, pathway (ii) is favored for the formation of the THF-derived amine 4a from the carbonyl-conjugated vinylfuran $1 \mathbf{a}$ over $\mathrm{Pd} / \mathrm{Al}_{2} \mathrm{O}_{3}$ (Scheme 2). First, the hydrogenation of $\mathbf{1 a}$ gives the furanic ketone 2a, followed by the deep hydrogenation to the THFderived ketone 3a. The subsequent reversible reaction of $\mathbf{3 a}$ and $\mathrm{NH}_{3}$ leads to the formation of the imine intermediate with concomitant $\mathrm{H}_{2} \mathrm{O}$ formation. Meanwhile, $4 \mathbf{a}$ reaches a maximum as the reaction proceeds. In light of these results, $\mathrm{Pd} / \mathrm{Al}_{2} \mathrm{O}_{3}$ appears as a very active and chemo-selective catalyst for promoting the transformation of $\mathbf{1 a}$ into $\mathbf{4 a}$ without the formation of undesirable byproducts.

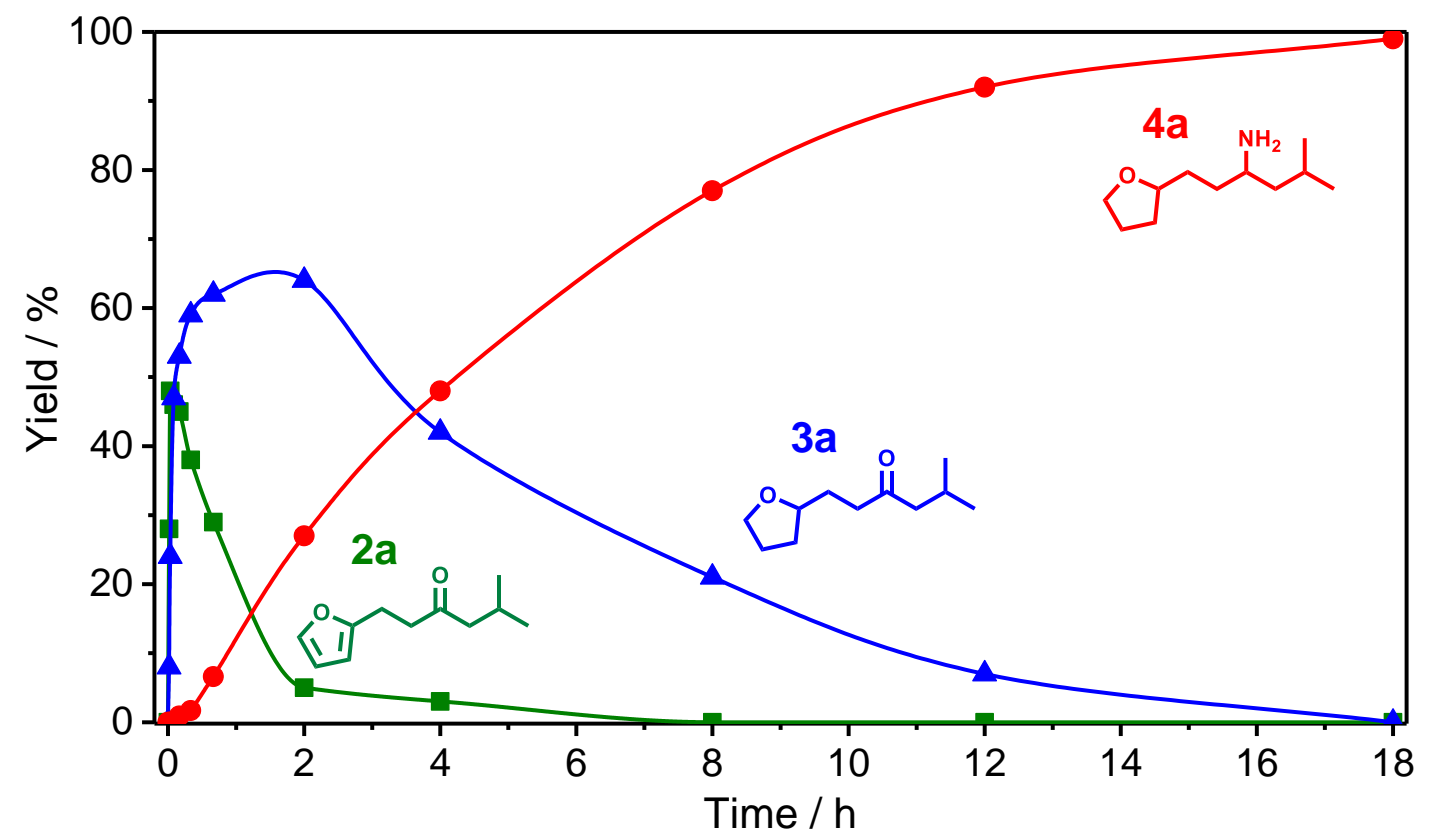

Figure 4. Time-evolution of the reaction products in the reductive amination of $1 \mathbf{a}$ over $\mathrm{Pd} / \mathrm{Al}_{2} \mathrm{O}_{3}$. Reaction conditions: $\mathrm{Pd} / \mathrm{Al}_{2} \mathrm{O}_{3}(10 \mathrm{mg}), \mathbf{1 a}(0.2 \mathrm{~g}), \mathrm{EtOH}$ (2 g), $\mathrm{NH}_{3}$ (5 bar), $\mathrm{H}_{2}$ (20 bar), $120{ }^{\circ} \mathrm{C}$.

Catalyst Recyclability. The recyclability of the $\mathrm{Pd} / \mathrm{Al}_{2} \mathrm{O}_{3}$ catalyst was evaluated in the reductive amination of 1a over a series of consecutive runs (Figure 5). After each run, the catalyst was 
recovered by centrifugation and reused without further reactivation. After the $2^{\text {nd }}$ run, the yield of 4a decreased slightly from $97 \%$ to $91 \%$, while product $3 \mathbf{a}$ appeared with $5 \%$ yield. After the $3^{\text {rd }}$ and $4^{\text {th }}$ runs, the product distribution fully changed, since the yield of $4 \mathbf{a}$ decreased to $<50 \%$ at the expense of 5a. One can mention that the recycled $\mathrm{Pd} / \mathrm{Al}_{2} \mathrm{O}_{3}$ catalyst behave like $\mathrm{Ru}$, $\mathrm{Pt}$ and $\mathrm{Rh} / \mathrm{Al}_{2} \mathrm{O}_{3}$ catalysts but with the formation of less by-products. After the $4^{\text {th }}$ run, the catalyst was recovered by filtration and washed with ethanol three times, dried overnight, calcined at $500{ }^{\circ} \mathrm{C}$ for $2 \mathrm{~h}$ and reduced under $\mathrm{H}_{2}$. The refreshed catalyst exhibited a yield of product $\mathbf{4 a}$ of $78 \%$ along with 13\% yield of 5a. Interestingly, no Pd loss was detected during the reaction, as inferred from ICP measurements in the reaction solution after the $4^{\text {th }}$ run. These results point out that Pd leaching is not at the origin of the observed catalyst deactivation. To explain this change in the selectivity, the spent catalyst after the $4^{\text {th }}$ run was subjected to characterization using different techniques.

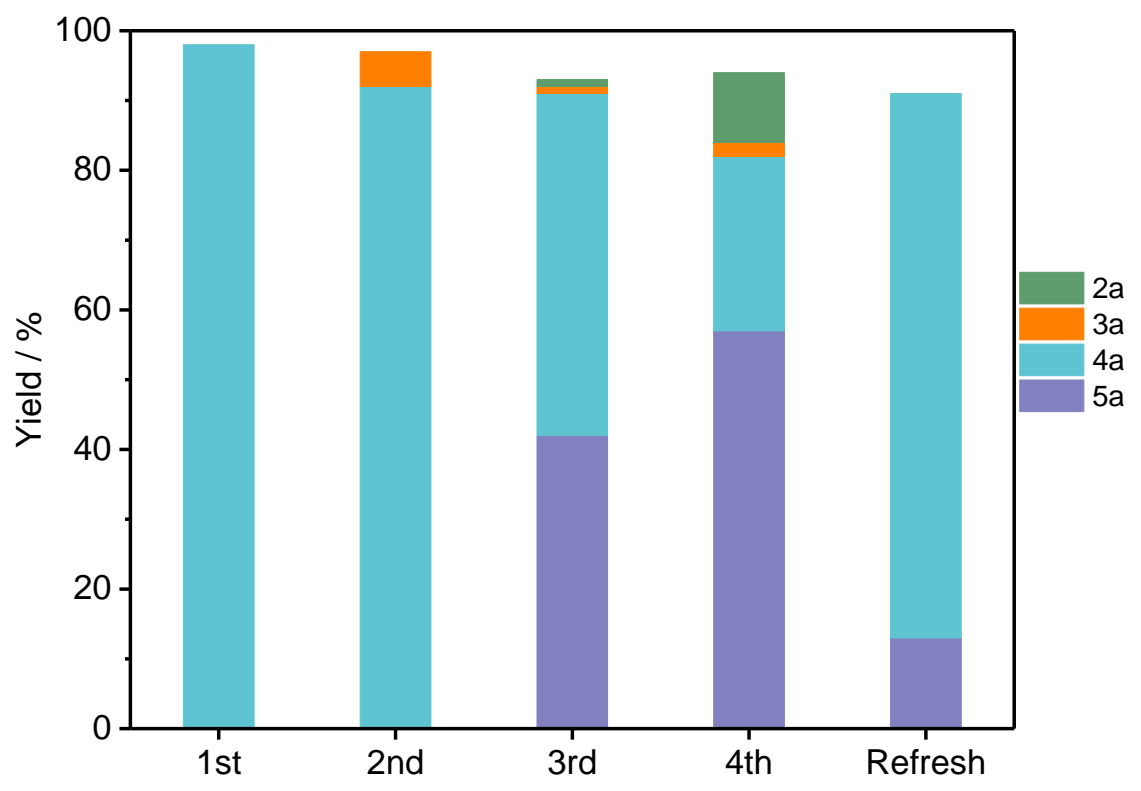

Figure 5. Product distribution in consecutive catalytic runs in the reductive amination of $\mathbf{1 a}$. Reaction conditions: $\mathrm{Pd} / \mathrm{Al}_{2} \mathrm{O}_{3}(20 \mathrm{mg}), \mathbf{1 a}(0.4 \mathrm{~g}), \mathrm{EtOH}(4 \mathrm{~g}), \mathrm{NH}_{3}(5 \mathrm{bar}), \mathrm{H}_{2}(20 \mathrm{bar}), 120{ }^{\circ} \mathrm{C}$, $20 \mathrm{~h}$. 
Characterization of Recycled $\mathbf{P d} / \mathrm{Al}_{2} \mathrm{O}_{3}$. Figure S3 plots the $\mathrm{N}_{2}$ adsorption/desorption curves at $77 \mathrm{~K}$ of the fresh and recycled $\mathrm{Pd} / \mathrm{Al}_{2} \mathrm{O}_{3}$ catalyst after the $4^{\text {th }}$ run, whereas Table 3 lists the textural properties. Although, both samples exhibited the presence of mesopores, the spent sample showed a slight decline of the specific surface area, pore volume and average pore size. This observation might be linked to the modification of the active sites leading to a different pathway driven by a change of the Pd particle, as well as by pore blockage due to coking or due to the adsorption of oligomers.

Table 3. Textural properties of the $\mathrm{Pd} / \mathrm{Al}_{2} \mathrm{O}_{3}$ catalysts.

\begin{tabular}{llll}
\hline $\mathrm{Pd} / \mathrm{Al}_{2} \mathrm{O}_{3}$ & $\mathrm{~S}_{\mathrm{BET}}\left(\mathrm{m}^{2} / \mathrm{g}\right)$ & Pore volume $\left(\mathrm{cm}^{3} / \mathrm{g}\right)$ & Pore size $(\mathrm{nm})$ \\
\hline Fresh & 158 & 0.57 & 14.4 \\
Recycled & 147 & 0.51 & 13.9 \\
\hline
\end{tabular}

TG analysis was then performed on the spent catalyst (Figure 6). The thermal profile of the fresh $\mathrm{Pd} / \mathrm{Al}_{2} \mathrm{O}_{3}$ exhibited three main regions i) at around $100{ }^{\circ} \mathrm{C}$ (water desorption; (ii) at about $200{ }^{\circ} \mathrm{C}$ (decomposition or vaporization of small organic molecules); and (iii) in the range of 250$600{ }^{\circ} \mathrm{C}$ (possible dehydration of the alumina support). The TG curve of the recycled $\mathrm{Pd} / \mathrm{Al}_{2} \mathrm{O}_{3}$ under air exhibited a quite different thermal profile. For the spent catalyst, three regions were observed in the temperature range $250-600{ }^{\circ} \mathrm{C}$ reflecting the possible formation of carbon deposits. Besides, the total weight loss increased from $9.7 \mathrm{wt} \%$ for the fresh catalyst to $12.3 \mathrm{wt} \%$ for the recycled catalyst. Thus the catalyst can be regenerated by calcination at $500{ }^{\circ} \mathrm{C}$. 


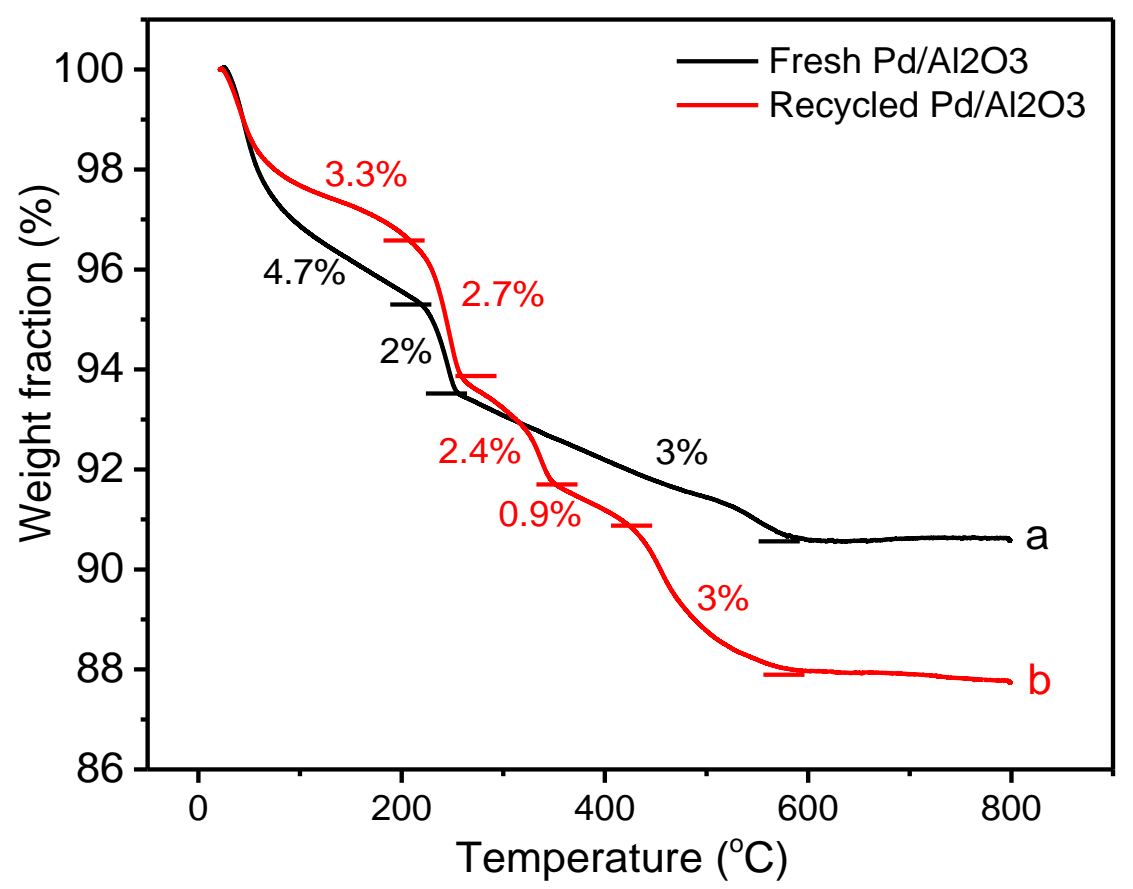

Figure 6. TG profiles of $\mathrm{Pd} / \mathrm{Al}_{2} \mathrm{O}_{3}$ under air: (a) fresh and (b) recycled catalyst after the $4^{\text {th }}$ run.

To further understand the nature of adsorbed species on the recycled $\mathrm{Pd} / \mathrm{Al}_{2} \mathrm{O}_{3}$, the catalyst was analyzed by FT-IR. Figure 7 shows the FT-IR spectra of the fresh, spent and regenerated $\mathrm{Pd} / \mathrm{Al}_{2} \mathrm{O}_{3}$. Two characteristic bands centered at $1157 \mathrm{~cm}^{-1}$ and $1230 \mathrm{~cm}^{-1}$ belonging to $\mathrm{C}-\mathrm{O}$ bonds in the furan ring were preserved after regeneration. ${ }^{57}$ Furthermore, by calcination at $500{ }^{\circ} \mathrm{C}$ for 1 $\mathrm{h}$, the carbon deposits could be almost completely removed.

To achieve more information on the catalyst surface, the recycled $\mathrm{Pd} / \mathrm{Al}_{2} \mathrm{O}_{3}$ was analyzed by XPS after $4^{\text {th }}$ run (Figure 8$)$ and it has two doublets with BE $\left(\operatorname{Pd~} 3 \mathrm{~d}_{5 / 2}\right) 335.1$ and $336.7 \mathrm{eV}$ attributed to metallic $\mathrm{Pd}^{0}$ and $\mathrm{Pd}^{2}+(\mathrm{PdO})$, respectively. ${ }^{58,59}$ Both of the states coexisting on the surface almost had no shift in comparison to that of fresh $\mathrm{Pd} / \mathrm{Al}_{2} \mathrm{O}_{3}(335.1$ and $336.9 \mathrm{eV})$. At the same time most of the $\mathrm{Pd}(82$ atom\%) still kept in metallic form, suggesting that the apparent change of selectivity is not attributed to Pd oxidation. 


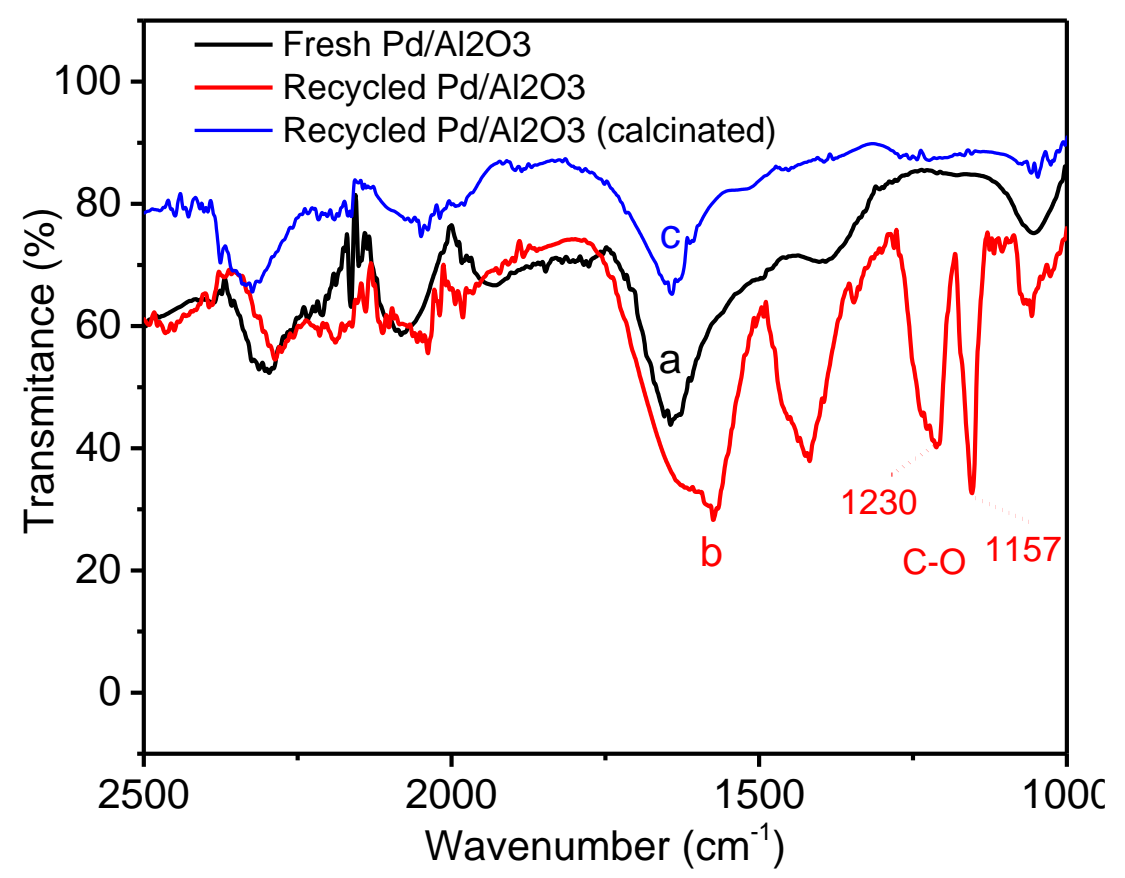

Figure 7. FT-IR spectra of (a) fresh, (b) recycled and (c) regenerated $\mathrm{Pd} / \mathrm{Al}_{2} \mathrm{O}_{3}$.
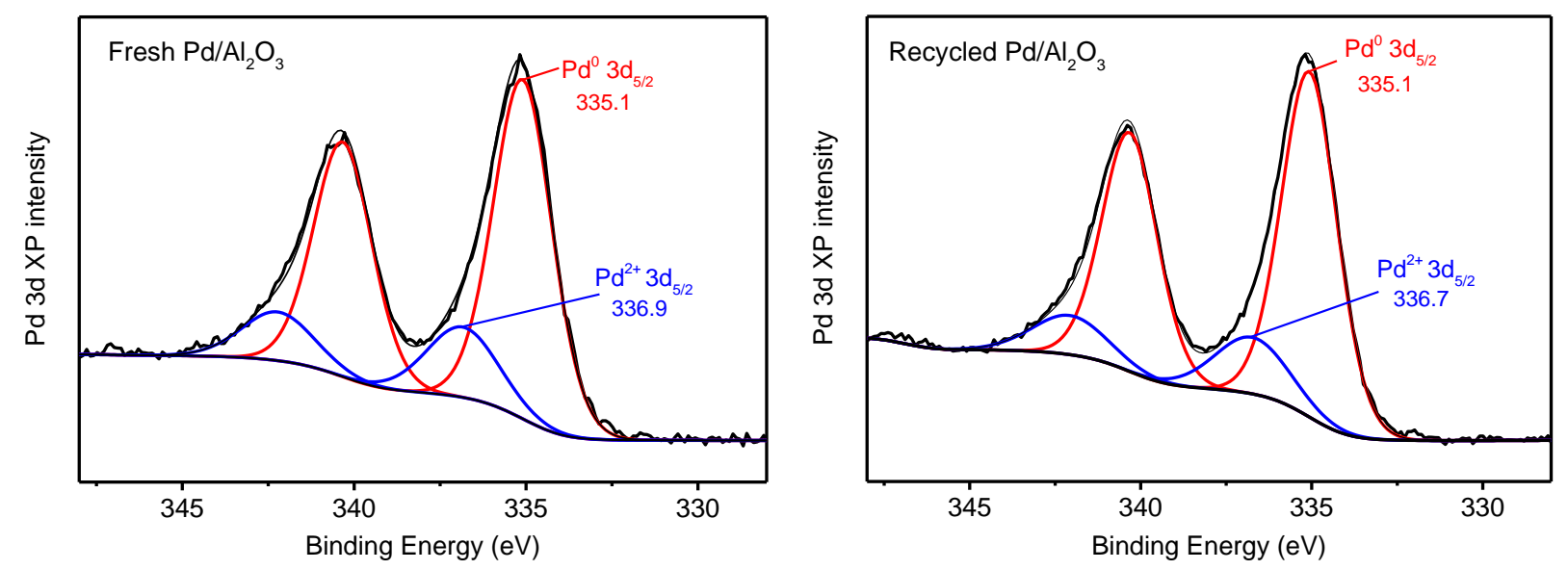

Figure 8. XPS Pd 3d spectra of fresh $\mathrm{Pd} / \mathrm{Al}_{2} \mathrm{O}_{3}$ and recycled $\mathrm{Pd} / \mathrm{Al}_{2} \mathrm{O}_{3}$.

Finally TEM was used to measure the size distribution and average size of Pd nanoparticles in the $\mathrm{Pd} / \mathrm{Al}_{2} \mathrm{O}_{3}$ catalyst before and after reaction (Figure 9). The recycled catalyst exhibits an obvious increase of the average size of the Pd nanoparticles from $2.3 \mathrm{~nm}$ to $4.7 \mathrm{~nm}$. In the meantime, a clear agglomeration of Pd nanoparticles is observed (Figure S4). Moreover, EDS analysis on the fresh and spent catalysts (Figure S5 and S6) confirmed the formation of carbon 
deposits during the reaction. Overall, catalyst deactivation during the reductive amination of 1a occurred mainly by two different pathways: (1) sintering/agglomeration of Pd nanoparticles, and (2) formation of carbon deposits on Pd. It seems that in the presence of used catalyst, the reaction pathway changed and the major route is reaction pathway (i) (Scheme 2).
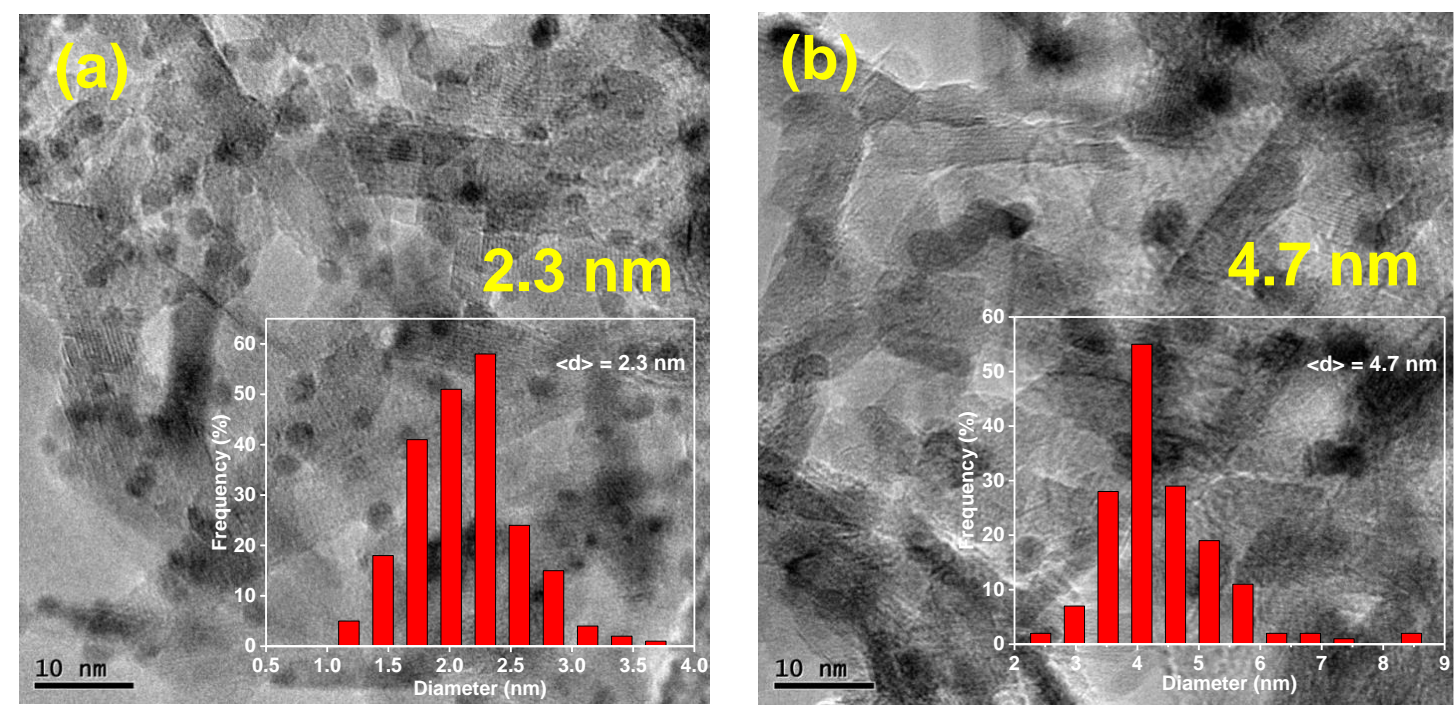

Figure 9. TEM micrographs of the catalyst and distribution of the Pd nanoparticle size. (a) Fresh $\mathrm{Pd} / \mathrm{Al}_{2} \mathrm{O}_{3} ;\left(\right.$ b) Recycled $\mathrm{Pd} / \mathrm{Al}_{2} \mathrm{O}_{3}$.

Substrate Scope. The scope of the reaction was further extended to the reductive amination of a series of furan-derived ketones over $\mathrm{Pd} / \mathrm{Al}_{2} \mathrm{O}_{3}$ (Table 4). The detailed reaction conditions are summarized in the SI. For all substrates, the corresponding amines were efficiently obtained with 91-98\% yield. These results clearly show that $\mathrm{Pd} / \mathrm{Al}_{2} \mathrm{O}_{3}$ can enable the efficient and selective synthesis of a large variety various THF-derived amines from the corresponding biomass-derived carbonyl vinylfurans. 
Table 4. THF-derived amines produced from furan-derived ketones over $\mathrm{Pd} / \mathrm{Al}_{2} \mathrm{O}_{3}$.

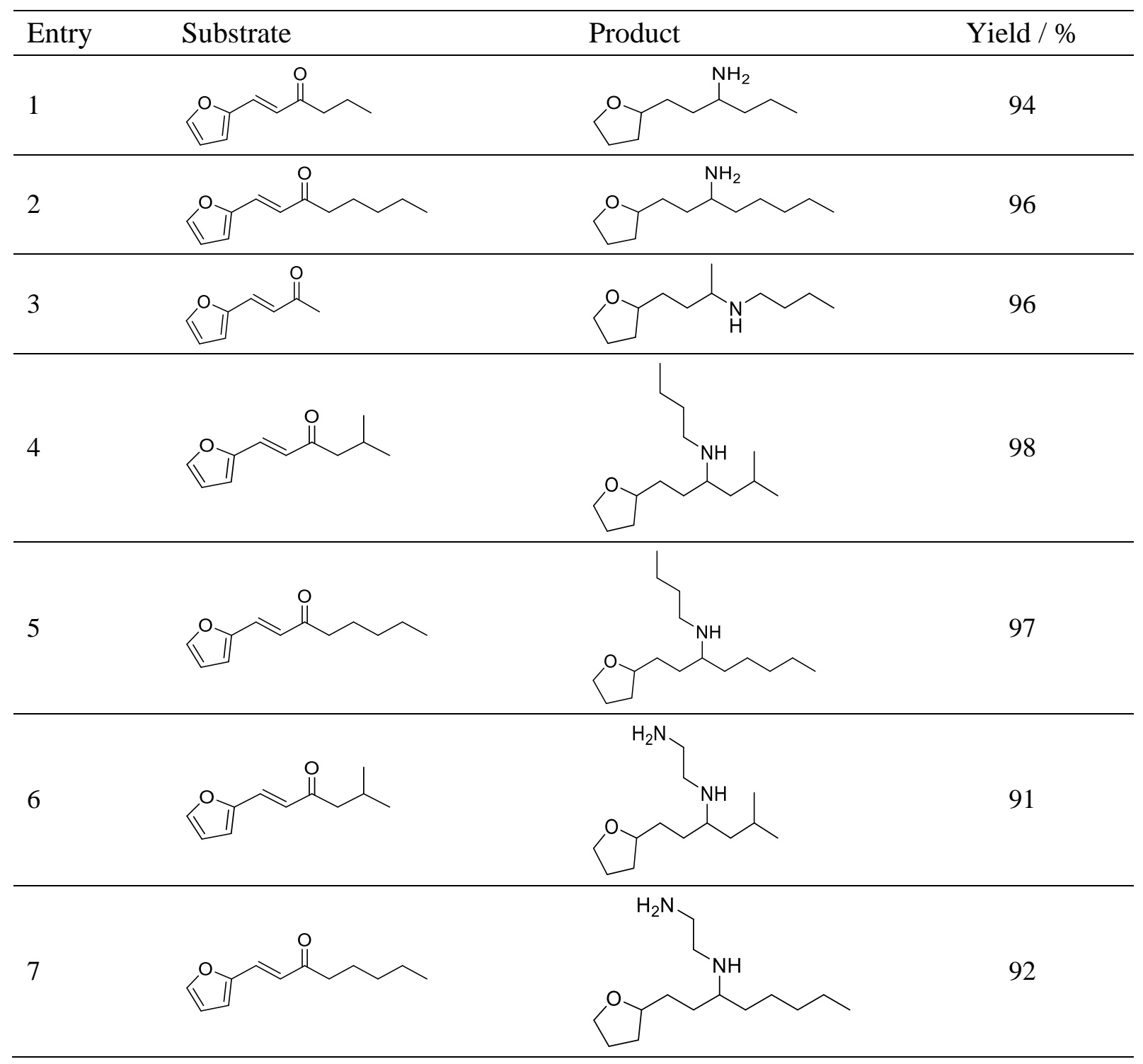

One pot two step reaction. It is highly desired to design intensified reactions in a single reactor avoiding the separation and purification of intermediates. In this view, first the aldol condensation reaction was optimized using Amberlyst-26 (A26) as catalyst to achieve high yield towards the carbonyl-conjugated vinylfuran $\mathbf{1 a}$ at an equimolar MIBK/furfural ratio in ethanol. When the reaction was conducted at $80{ }^{\circ} \mathrm{C}$ with an $\mathrm{A} 26 /$ furfural weight ratio of $40 \mathrm{wt} \%$, a maximum yield 
of $4 \mathbf{a}$ of $90 \%$ was achieved after $6 \mathrm{~h}$ with $99 \%$ furfural conversion (Figure S8). Furthermore, when the MIBK/furfural molar ratio increased to 1.2, 96\% yield of $1 \mathrm{a}$ was achieved after $6 \mathrm{~h}$ at $80{ }^{\circ} \mathrm{C}$.

Table 5. Catalytic conversion of furfural to THF-derived amine (4a) with Amberlyst-26 and $\mathrm{Pd} / \mathrm{Al}_{2} \mathrm{O}_{3}$ solid catalysts in a one-reactor process. ${ }^{\mathrm{a}}$

\begin{tabular}{|c|c|c|c|c|c|c|c|c|c|c|}
\hline \multirow[b]{2}{*}{ Entry } & \multirow[b]{2}{*}{ Substrate } & \multicolumn{2}{|c|}{ Catalyst (wt\%) } & \multicolumn{2}{|c|}{ Time (h) } & \multirow{2}{*}{$\begin{array}{l}P \mathrm{H}_{2} \\
\text { (bar) }\end{array}$} & \multicolumn{4}{|c|}{ Yield (\%) } \\
\hline & & $\begin{array}{l}\text { A- } \\
26\end{array}$ & $\mathrm{Pd} / \mathrm{Al}_{2} \mathrm{O}_{3}$ & $1^{\mathrm{st}}$ & $2^{\text {nd }}$ & & $2 \mathbf{a}$ & $\mathbf{3 a}$ & $\mathbf{4 a}$ & $5 \mathbf{a}$ \\
\hline $1^{b}$ & $\mathbf{1 a}$ & - & 5 & - & 20 & 20 & n.d. & n.d. & 98 & n.d. \\
\hline $2^{c}$ & Furfural & 40 & 5 & 6 & 20 & 20 & 10 & 29 & 36 & 6 \\
\hline 3 & Furfural & 40 & 5 & 6 & 20 & 20 & n.d. & 23 & 60 & n.d. \\
\hline 4 & Furfural & 40 & 5 & 6 & 40 & 20 & n.d. & 11 & 74 & n.d. \\
\hline 5 & Furfural & 40 & 5 & 6 & 20 & 40 & n.d. & 10 & 75 & n.d. \\
\hline 6 & Furfural & 40 & 10 & 6 & 20 & 20 & n.d. & 11 & 74 & n.d. \\
\hline $7^{\mathrm{d}}$ & Furfural & 40 & 10 & 6 & 20 & 20 & n.d. & 9 & 85 & n.d. \\
\hline
\end{tabular}

${ }^{\text {a }}$ Furfural conversion was $100 \%$ for all the reactions. $\left(1^{\text {st }}\right)$ All runs were carried out at $80{ }^{\circ} \mathrm{C}$ in $2 \mathrm{~g}$ EtOH with $108 \mathrm{mg}$ furfural while keeping an equimolar MIBK/furfural ratio and an Amberlyst-26/furfural weight ratio of $40 \mathrm{wt} \%$, (2 $\left.{ }^{\text {nd }}\right)$ the reductive amination reactions were all following the first step of aldol condensation, the mass ratio of $\mathrm{Pd} / \mathrm{Al}_{2} \mathrm{O}_{3}-$ theoretical 1a 5 wt \%, 5 bar $\mathrm{NH}_{3}, \mathrm{H}_{2}$.

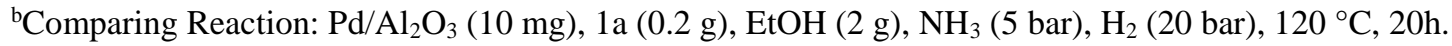

${ }^{\mathrm{c}} \mathrm{Pd} / \mathrm{Al}_{2} \mathrm{O}_{3}$ was added with Amberlyst-26 at the beginning of the reaction.

${ }^{\mathrm{d}}$ The MIBK/furfural molar ratio was 1.2/1.

The one-reactor catalytic tests were further carried out using a physical mixture of A26 and $\mathrm{Pd} / \mathrm{Al}_{2} \mathrm{O}_{3}$ (Table 5). A yield of $36 \%$ to product $4 \mathbf{a}$ was obtained together with a complex mixture of hydrogenated products and amines (entry 2). A much higher yield (60\%) of $\mathbf{4 a}$ was obtained when $\mathrm{Pd} / \mathrm{Al}_{2} \mathrm{O}_{3}$ was added during the reductive amination step (entry 3 ). The reaction conditions of the second step were further optimized to increase further the yield of product $\mathbf{4 a}$ (entries 4-6). A yield of product $4 \mathbf{a}$ up to $75 \%$ with $10 \%$ yield of product $3 \mathbf{a}$ could be achieved by increasing the reaction time from $20 \mathrm{~h}$ to $40 \mathrm{~h}$, the $\mathrm{H}_{2}$ pressure from 20 bar to 40 bar, or the $\mathrm{Pd} / \mathrm{Al}_{2} \mathrm{O}_{3}$ amount from $5 \mathrm{wt} \%$ to $10 \mathrm{wt} \%$. By increasing the MIBK/furfural molar ratio in the first step to 1.2 to 
promote the formation of the aldolization product 1a, a maximum yield of $85 \%$ of product 4 a could be achieved in the presence of $10 \mathrm{wt} \% \mathrm{Pd} / \mathrm{Al}_{2} \mathrm{O}_{3}$ (entry 7).

\section{Conclusion}

In summary, a new family of THF-derived amines was selectively synthesized with $~ 98 \%$ yield starting from bio-derived ketones using $\mathrm{NH}_{3}$ or amines as a nitrogen source, molecular hydrogen as a reducing agent and $\mathrm{Pd} / \mathrm{Al}_{2} \mathrm{O}_{3}$ as catalyst. This system efficiently catalyzed the hydrogenation of the unsaturated $\mathrm{C}=\mathrm{C}$ bond and the reductive amination of the carbonyl group at mild reaction conditions in a single reactor. Although no Pd leaching from the catalyst was evidenced during the reaction, a change of the catalyst selectivity was observed after the $3^{\text {rd }}$ catalytic run mostly due to the Pd sintering and the deposit of carbon species. Besides, furfural could be converted into functionalized THF-amine in a one-pot two steps process without any purification between the two steps and with a yield up to $85 \%$. Thus, our present work opens a new avenue for producing biobased amines with high potential for the synthesis of biosolvents or biosurfactants. Besides, this study provides a toolbox that enables the sustainable conversion of furfural into target THF-derived amines. The deposition of Pd over a multifunctional supports and the design of a continuous flow processes are current lines of investigation to optimize the performance of the one-reactor process.

\section{ASSOCIATED CONTENT}

Supporting Information. A listing of the contents of each file supplied as Supporting Information should be included. For instructions on what should be included in the Supporting Information as well as how to prepare this material for publications, refer to the journal's 
Instructions for Authors.

Corresponding Authors

*marc.pera-titus-ext@solvay.com

*karine.vigier@univ-poitiers.fr

\section{Author Contributions}

\section{Funding Sources}

ANR agency for the funding of FurCab Project ANR-15-CE07-0016. Région Nouvelle Aquitaine for the funding of this project through the FR CNRS INCREASE 3707, the chaire TECHNOGREEN and FEDER, the University of Poitiers and the CNRS for their financial support.

Notes

Any additional relevant notes should be placed here.

\section{ACKNOWLEDGMENT}

The authors would like to thank the ANR agency for the funding of FurCab Project ANR-15CE07-0016. Authors are also grateful to the Région Nouvelle Aquitaine for the funding of this project through the FR CNRS INCREASE 3707, the chaire TECHNOGREEN and FEDER. CNRS and University of Poitiers are also acknowledged.

\section{ABBREVIATIONS}

THF, tetrahydrofuran; MIBK, methyl isobutyl ketone.

\section{REFERENCES}


(1) Lawrence, S. A. Amines: Synthesis, Properties and Applications; Cambridge University Press, 2004.

(2) Koutinas, A. A.; Du, C.; Wang, R. H.; Webb, C. Introduction to Chemicals from Biomass, Wiley, Hoboken, 2008, pp. 77.

(3) Gandini, A.; Lacerda, T. M.; Carvalho, A. J. F.; Trovatti, E. Progress of Polymers from Renewable Resources: Furans, Vegetable Oils, and Polysaccharides. Chem. Rev. 2016, 116, 1637-1669.

(4) Delidovich, I.; Hausoul, P. J. C.; Deng, L.; Pfützenreuter, R.; Rose, M.; Palkovits, R. Alternative Monomers Based on Lignocellulose and Their Use for Polymer Production. Chem. Rev. 2016, 116, 1540-1599.

(5) Willcox, D.; Chappell, B. G. N.; Hogg, K. F.; Calleja, J.; Smalley, A. P.; Gaunt, M. J. A General Catalytic $\beta$-C-H Carbonylation of Aliphatic Amines to $\beta$-Lactams. Science 2016, $354,851-857$.

(6) Jagadeesh, R. V.; Murugesan, K.; Alshammari, A. S.; Neumann, H.; Pohl, M.-M.; Radnik, J.; Beller, M. MOF-derived Cobalt Nanoparticles Catalyze a General Synthesis of Amines. Science 2017, 358, 326-332.

(7) Pelckmans, M.; Renders, T.; Van de Vyver S.; Sels, B. F. Bio-Based Amines through Sustainable Heterogeneous Catalysis. Green Chem. 2017, 19, 5303-5331.

(8) Froidevaux, V.; Negrell, C.; Caillol, S.; Pascault, J.-P.; Boutevin, B. Biobased Amines: From Synthesis to Polymers; Present and Future. Chem. Rev. 2016, 116, 14181-14224.

(9) Talwar, D.; Salguero, N. P.; Robertson, C. M.; Xiao, J. Primary Amines by Transfer Hydrogenative Reductive Amination of Ketones by Using Cyclometalated Ir $^{\mathrm{III}}$ Catalysts. Chem. Eur. J. 2014, 20, 245-252. 
(10) Senthamarai T.; Murugesan, K.; Schneidewind, J.; Kalevaru, N. V.; Baumann, W.; Neumann, H.; Kamer, P. C. J.; Beller, M.; Jagadeesh, R. V. Simple ruthenium-catalyzed reductive amination enables the synthesis of a broad range of primary amines. Nat. Commun. 2018, $9,4123$.

(11) Tan, X.; Gao, S.; Zeng, W.; Xin, S.; Yin, Q.; Zhang, X. Asymmetric Synthesis of Chiral Primary Amines by Ruthenium Catalyzed Direct Reductive Amination of Alkyl Aryl Ketones with Ammonium Salts and Molecular H2. J. Am. Chem. Soc. 2018, 140, 2024-2027.

(12) Roose, P.; Eller, K.; Henkes, E.; Rossbacher, R.; Höke, H. Amines, Aliphatic, Ullmann's Encyclopedia of Industrial Chemistry; Wiley-VCH: Weinheim, 2015; pp 1-55.

(13) Deng, W.; Wang, Y.; Zhang, S.; Gupta, K. M.; Hülsey, M. J.; Asakura, H.; Liu, L.; Han, Y.; Karp, E. M.; Beckham, G. T.; Dyson, P. J.; Jiang, J.; Tanaka, T.; Wang, Y.; Yan, N. Catalytic amino acid production from biomass-derived intermediates. PNAS, 2018, 115(20), 50935098.

(14) Li, H.; Guo, H.; Su, Y.; Hiraga, Y.; Fang, Z.; Hensen, E. J. M.; Watanabe, M.; Smith, R. L. N-formyl-stabilizing quasi-catalytic species afford rapid and selective solvent-free amination of biomass-derived feedstocks. Nat. Commun. 2019, 10, 699.

(15) Yan, N.; Chen, X. Don’t Waste Seafood Waste. Nature, 2015, 524, 155-157

(16) Brun, N.; Hesemann, P.; Esposito, D. Expanding the Biomass Derived Chemical Space. Chem. Sci. 2017, 8, 4724-4738

(17) Imm, S.; Bahn, S.; Zhang, M.; Neubert, L.; Neumann, H.; Klasovsky, F.; Pfeffer, J.; Haas, T.; Beller, M. Improved Ruthenium-Catalyzed Amination of Alcohols with Ammonia: Synthesis of Diamines and Amino Esters. Angew. Chem. Int. Ed. 2011, 50, 7599-7603. 
(18) Chatterjee, M.; Ishizaka, T.; Kawanami, H. Reductive Amination of Furfural to Furfurylamine Using Aqueous Ammonia Solution and Molecular Hydrogen: an Environmentally Friendly Approach. Green Chem. 2016, 18, 487-496.

(19) Pelckmans, M.; Vermandel, W.; Waes, F. V.; Mooen, K.; Sels, B. F. Low-Temperature Reductive Aminolysis of Carbohydrates to Diamines and Aminoalcohols by Heterogeneous Catalysis. Angew. Chem. Int. Ed. 2017, 56, 14540-14544.

(20) Liang, G.; Wang, A.; Li, L.; Xu, G.; Yan, N.; Zhang, T. Production of Primary Amines by Reductive Amination of BiomassDerived Aldehydes/Ketones. Angew. Chem. Int. Ed. 2017, $56,3050-3054$.

(21) Niemeier, J.; Engel, R. V.; Rose, M. Is Water a Suitable Solvent for the Catalytic Amination of Alcohols? Green chem. 2017, 19, 2839-2845.

(22) Knaus, T.; Böhmer, W.; Mutti, F. G. Amine Dehydrogenases: Efficient Biocatalysts for the Reductive Amination of Carbonyl Compounds. Green Chem. 2017, 19, 453-463.

(23) Yan, T.; Feringa, B. L.; Barta, K. Iron Catalysed Direct Alkylation of Amines with Alcohols. Nat. Commun. 2014, 5, 5602-5609.

(24) Elangovan, S.; Neumann, J.; Sortais, J.-B.; Junge, K.; Darcel, C.; Beller, M. Efficient and Selective N-Alkylation of Amines with Alcohols Catalysed by Manganese Pincer Complexes. Nat. Commun. 2016, 7, 12641-12649.

(25) Gomez, S.; Peters, J. A.; Maschmeyer, T. The Reductive Amination of Aldehydes and Ketones and the Hydrogenation of Nitriles Mechanistic Aspects and Selectivity Control. Adv. Synth. Catal. 2002, 344, 1037-1057.

(26) Utusunomiya, M.; Kuwano, R.; Kawatsura, M.; Hartwig, J. F. Rhodium-Catalyzed AntiMarkovniko Hydroamination of Vinylarenes. J. Am. Chem. Soc. 2003, 125, 5608-5609. 
(27) Ogo, S.; Uehara, K.; Abura, T.; Fukuzumi, S. pH-Dependent Chemoselective Synthesis of $\alpha$-Amino Acids. Reductive Amination of $\alpha$-Keto Acido Acids with Ammonia Catalyzed by Acid-Stable Iridium Hydride Complexes in Water. J. Am. Chem. Soc. 2004, 126, 3020-3021.

(28) Maya, R. J.; Poulose, S.; John, J.; Varma, R. L. Direct Reductive Amination of Aldehydes via Environmentally Benign Bentonite-Gold Nanohybrid Catalysis. Adv. Synth. Catal. 2017, $359,1177-1184$.

(29) Gallardo-Donaire, J.; Ernst, M.; Trapp, O.; Schaub, T. Direct Synthesis of Primary Amines via Ruthenium-Catalysed Amination of Ketones with Ammonia and Hydrogen. Adv. Synth. Catal. 2016, 358, 358-363.

(30) Gross, T.; Seayad, A. M.; Ahmad, M.; Beller, M. Synthesis of Primary Amines: First Homogeneously Catalyzed Reductive Amination with Ammonia. Org. Lett. 2002, 41, 20552058.

(31) Yuan, H.; Li, J.; Su, F.; Yan, Z.; Kusema, B. T.; Streiff, S.; Huang, Y.; Pera-Titus, M.; Shi, F. Reductive Amination of Furanic Aldehydes in Aqueous Solution over Versatile $\mathrm{Ni}_{\mathrm{y}} \mathrm{AlO}_{\mathrm{x}}$ Catalysts. ACS Omega 2019, 4, 2510-2516.

(32) Deng, D.; Kita, Y.; Kamata, K.; Hara, M. Low-Temperature Reductive Amination of Carbonyl Compounds over $\mathrm{Ru}$ Deposited on $\mathrm{Nb}_{2} \mathrm{O}_{5} \cdot \mathrm{nH}_{2} \mathrm{O}$. ACS Sustainable Chem. Eng. 2019, 7, 4692-4698.

(33) Manzoli, M.; Gaudino, E. C.; Cravotto, G.; Tabasso, S.; Baig, R. B. N.; Colacino, E.; Varma, R. S. Microwave-Assisted Reductive Amination with Aqueous Ammonia: Sustainable Pathway Using Recyclable Magnetic Nickel-Based Nanocatalyst. ACS Sustainable Chem. Eng. 2019, 7, 5963-5974. 
(34) Murugesan, K.; Beller, M.; Jagadeesh R. V. Reusable Nickel Nanoparticles-catalyzed Reductive Amination for Selective Synthesis of Primary Amines. Angew. Chem. 2019, 131, 5118-5122.

(35) Zhang, Y.; Yang, H.; Chi, Q.; Zhang, Z. Nitrogen-doped carbon supported nickel nanoparticles: a robust catalyst to bridge the hydrogenation of nitriles and the reductive amination of carbonyl compounds for the synthesis of primary amines. ChemSusChem 2019, $12,1246-1255$.

(36) Jiang, S.; Verrier, C.; Ahmar, M.; Lai, J.; Ma, C.; Muller, E.; Queneau, Y.; Pera-Titus, M.; Jérôme, F.; De Oliveira Vigier, K. Unveiling the Role of Choline Chloride in Furfural Synthesis from Highly Concentrated Feeds of Xylose. Green Chem. 2018, 20, 5104-5110.

(37) Mariscal, R.; Maireles-Torres, P.; Ojeda, M.; Sádaba, I.; López Granados, M. Furfural: A Renewable and Versatile Platform Molecule for the Synthesis of Chemicals and Fuels. Energy Environ. Sci. 2016, 9, 1144-1189.

(38) Li, X.; Jia, P.; Wang, T. Furfural: A Promising Platform Compound for Sustainable Production of C4 and C5 Chemicals. ACS Catal. 2016, 6, 7621-7640.

(39) Komanoya, T.; Kinemura, T.; Kita, Y.; Kamata, K.; Hara, M. Electronic Effect of Ruthenium Nanoparticles on Efficient Reductive Amination of Carbonyl Compounds. J. Am. Chem. Soc. 2017, 139, 11493-11499.

(40) Chandra, D.; Inoue, Y.; Sasase, M.; Kitano, M.; Bhaumik, A.; Kamata, K.; Hosono, H.; Hara, M. A High Performance Catalyst of Shape-Specific Ruthenium Nanoparticles for Production of Primary Amines by Reductive Amination of Carbonyl Compounds. Chem. Sci. 2018, 9 , $5949-5956$ 
(41) Huber, G. W.; Chheda, J. N.; Barrett, C. J.; Dumesic, J. A. Production of Liquid Alkanes by Aqueous-Phase Processing of Biomass-Derived Carbohydrates. Science 2005, 308, 14461450.

(42) Sutton, A. D.; Waldie, F. D.; Wu, R.; Schlaf, M.; Silks, L. A. P., III; Gordon, J. C. The Hydrodeoxygenation of Bioderived Furans into Alkanes. Nat. Chem. 2013, 5, 428-432.

(43) Julis, J.; Leitner, W. Synthesis of 1-Octanol and 1,1-Dioctyl Ether from Biomass-Derived Platform Chemicals. Angew. Chem. Int. Ed. 2012, 51, 8615-8619.

(44) Xia, Q.; Xia, Y.; Xi, J.; Liu, X.; Wang, Y. Energy-Efficient Production of 1-Octanol from Biomass-Derived Furfural-Acetone in Water. Green Chem. 2015, 17, 4411-4417.

(45) Shao, Y.; Xia, Q.; Liu, X.; Lu, G.; Wang, Y. Pd/ $\mathrm{Nb}_{2} \mathrm{O}_{5} / \mathrm{SiO}_{2}$ Catalyst for the Direct Hydrodeoxygenation of Biomass-Related Compounds to Liquid Alkanes under Mild Conditions. ChemSusChem 2015, 8, 1761-1767.

(46) Li, M.; Xu, X.; Gong, Y.; Wei, Z.; Hou, Z.; Li, H.; Wang, Y. Ultrafinely Dispersed Pd Nanoparticles on a CN@MgO Hybrid as a Bifunctional Catalyst for Upgrading Bioderived Compounds. Green Chem. 2014, 16, 4371-4377.

(47) Luska, K. L.; Bordet, A.; Tricard, S.; Sinev, I.; Grünert, W.; Chaudret, B.; Leitner, W. Enhancing the Catalytic Properties of Ruthenium Nanoparticle-SILP Catalysts by Dilution with Iron. ACS Catal. 2016, 6, 3719-3726.

(48) Xu, J.; Li, N.; Yang, X.; Li, G.; Wang, A.; Cong, Y.; Wang, X.; Zhang, T. Synthesis of Diesel and Jet Fuel Range Alkanes with Furfural and Angelica Lactone. ACS Catal. 2017, 7, 5880-5886. 
(49) Xu, J.; Li, L.; Li, G.; Wang, A.; Cong, Y.; Wang, X.; Li, N. Synthesis of Renewable $\mathrm{C}_{8}-\mathrm{C}_{10}$ Alkanes with Angelica Lactone and Furfural from Carbohydrates. ACS Sustainable Chem. Eng. 2018, 6, 6126-6134.

(50) Rojas-Buzo, S.; García-García, P.; Corma, A. Hf-Based Metal-Organic Frameworks as Acid-Base Catalysts for the Transformation of Biomass-Derived Furanic Compounds into Chemicals. Green Chem. 2018, 20, 3081-3091.

(51) Yang, J.; Li, N.; Li, G.; Wang, W.; Wang, A.; Wang, X.; Cong, Y.; Zhang, T. Solvent-Free Synthesis of $\mathrm{C}_{10}$ and $\mathrm{C}_{11}$ Branched Alkanes from Furfural and Methyl Isobutyl Ketone. ChemSusChem 2013, 6, 1149-1152.

(52) Lee, R.; Vanderveen, J. R.; Champagne, P.; Jessop, P. G.; $\mathrm{CO}_{2}$-Catalysed aldol condensation of 5-hydroxymethylfurfural and acetone to a jet fuel precursor. Green Chem. 2016, 18, 51185121.

(53) He, X.; Conner, A. H.; Koutsky, J. A. Evaluation of furfurylamines as curing agents for epoxy resins. J. Polym. Sci., Part A: Polym. Chem. 1992, 30, 533-542

(54) Zhu, Y.; Batchelor, R.; Lowe, A. B.; Roth, P. J. Design of Thermoresponsive Polymers with Aqueous LCST, UCST, or Both: Modification of a Reactive Poly(2-vinyl-4,4dimethylazlactone) Scaffold. Macromolecules 2016, 49, 672-680.

(55) Liu, Y.; Zhou, K.; Shu, H.; Liu, H.; Lou, J.; Guo, D.; Wei, Z.; Li, X. Switchable synthesis of furfurylamine and tetrahydrofurfurylamine from furfuryl alcohol over RANEY® nickel. Catal. Sci. Technol. 2017, 7, 4129-4135.

(56) Jiang, S.; Muller, E.; Pera-Titus, M.; Jerôme, F.; De Oliveira Vigier, K. Direct catalytic conversion of furfural to furan-derived amines, Green Chem. 2019, submitted. 
(57) Tian, Q.; Yuan, Y. C.; Rong, M. Z.; Zhang, M. Q. A Thermally Remendable Epoxy Resin. J. Mater. Chem. 2009, 19, 1289-1296.

(58) Wang, Y.; Yao, J.; Li, H.; Su, D.; Antonietti, M. Highly Selective Hydrogenation of Phenol and Derivatives over a Pd@Carbon Nitride Catalyst in Aqueous Media. J. Am. Chem.Soc. 2011, 133, 2362-2365.

(59) Ainembabazi, D.; An, N.; Manayil, J. C.; Wilson, K.; Lee, A. F.; Voutchkova-Kostal, A. M. Acceptorless Amine Dehydrogenation and Transamination Using Pd-Doped Hydrotalcites. ACS Catal. 2019, 9, 1055-1065. 
BRIEFS (Word Style "BH_Briefs"). If you are submitting your paper to a journal that requires a brief, provide a one-sentence synopsis for inclusion in the Table of Contents.

\section{SYNOPSIS}

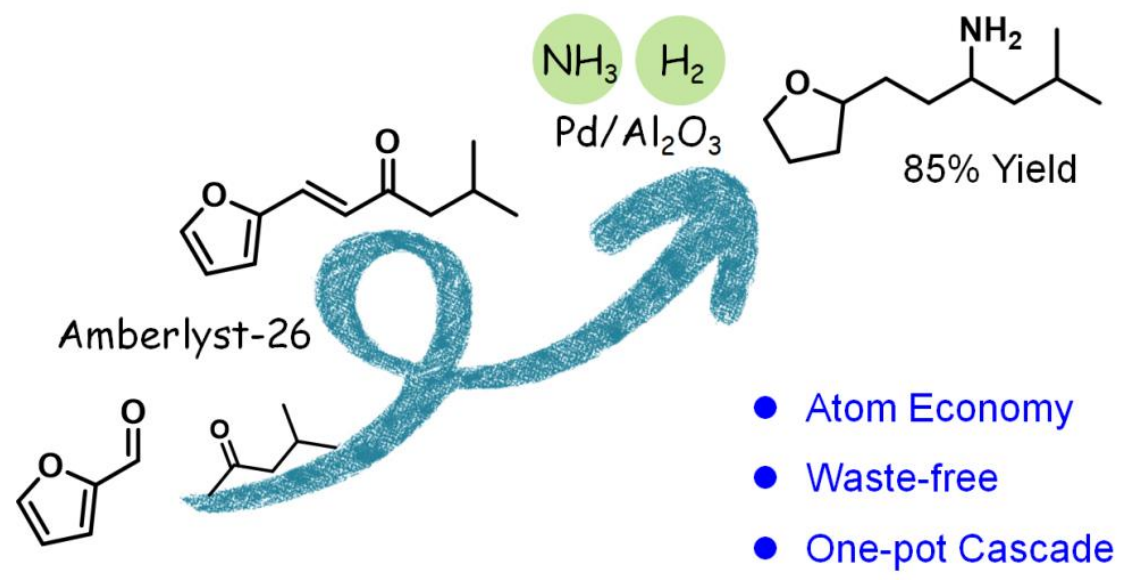

